\title{
News from the European Society for Experimental Surgery
}

\section{Committee Members for 1970/1971}

President:

Prof. Dr. T. Longo, II Clinica Chirurgica dell’'Università di Milano, Via Lamar-mora 11, 20122 Milano, Italy, Tel. 554072

1st Vice-President:

Doc. S. Bengmark, Kir. Klin. II, Sahlgrenska Sjukhuset, University of Göteborg, 41345 Göteborg SV, Sweden, Tel. 410010

2nd Vice-President:

Doc. P. J. Klopper, Chirurgische Kliniek, Wilhelmina Gasthuis, Le Helmersstraat, NL-Amsterdam

Treasurer:

Dr. med. S. M. Perren, Laboratorium für Experimentelle Chirurgie, Schweiz. Forschungsinstitut, CH-7270 Davos-Platz, Switzerland, Tel. 083/3

5210

Secretary General:

Dr. Chr. Marchal, Lab. de Chirurgie Expérimentale, 30, rue Lionnois, F-54 Nancy, Tel. 242833

Past Presidents:

Prof. Dr. R. Benichoux, Lab. der Chirurgie Expérimentale, 30, rue Lionnois,

F-54 Nancy Prof. Dr. J. J. Haxńe, Lab. de Chirurgie Expérimentale, 69, rue de Bruxelles,

Louvain, Belgium Prof. Dr. W. Brendel, Institut für Experimentelle Chirurgie, Chirurgische Univer-

sitätsklinik, Nussbaumstrasse 20, 8 München 15, Germany PD Dr. med. U. F. Gruber, Chirurgische Universitätsklinik Bürgerspital, $C H-4000$

Basel, Switzerland

II. Miscellaneous

The 5th Congress of the European Society for Experimental Surgery was successfully held at the Lido, Venice, Italy, from May 10 to May 13 ,

1970. The meeting was attended by some 600 persons from 28 different countries. The Congress was organized in two separate sections, at which

a total of 140 papers on the following topics was presented and discussed:

Tissue Typing and Immunosuppression in Organ Transplant

Experimental Cardiac Surgery and Myocardial Metabolism

Physiopathology with particular reference to the liver

Experimental Surgical Techniques. 18 films were shown.

News from the European Society for Experimental Surgery 319

\section{ПII. Next Congress}

During the plenary session it was decided that the next Congress will be held in Hẫlsingborg, Sweden, from april 26-28, 1971 and will be organized under the responsability of the first Vice-President, Docent Stig Bengmark of the University of Göteborg.

\section{The annual Prize of the European Society for Experimental Surgery}

The prize of the European Society for Experimental Surgery 1970 was divided and given to the authors of the following two papers submitted for publication in European Surgical Research:

K. L. Appelgren and D. H. Lewis, Department of Surgery I, University of Göteborg, Sweden (published in European Surgical Research, Vol. 2, No. 3, pp. 161-170, 1970): 'Capillary flow and capillary transport in dog skeletal muscle after induced intravascular RBC aggregation and disaggregation.'

L. Lambotte, Department of Experimental Surgery, Catholic University of Lou-vain, Belgium (published in European Surgical Research, Vol. 2, No. 4, pp. 241-250, 1970): 'Hepatic cell membrane potential, a new assay for preserved organs viability.'

The European Society for Experimental Surgery has decided to award at the next annual congress in Sweden a

Prize in the amount of 5,000.- DM

to the author or authors of the

best paper published or submitted for publication in European Surgical Research before January 31st, 1971.

V. Editor's Note

a) By decision of the Editorial board Letters to the Editor will be accepted for publication in ESR.

These letters should refer directly to an article published in ESR and should not contain more than 200 words including the mailing address of the author. The letters will be submitted to the author to whose paper they refer; his comment will be published together with the Letter to the Editor.

b) The abstract issue of the next volumes of ESR will appear soon after the

congress, in order to obtain the whole information of the papers presented at the

annual meeting.

320 News from the European Society for Experimental Surgery

VI. Seminar on Cardiac Assist

The European Society for Experimental Surgery has accepted to sponsor a Seminar on Cardiac Assist to be held in Nancy during the first week of October 1971 (Monday and Tuesday, 4-5 October). 
This Meeting will be organized by the Institut de Recherches Chirurgicales of Nancy (R. Benichoux) and the Centre d'Etudes de Techniques Chirurgicales de ГHôpital Broussais of Paris (J. P. Cachera and Ch. Dubost).

It will take place in the Abbaye des Prémontres in Pont-à-Mousson, nearby Nancy. Members of our Society may well remember this place where the first Meeting of our Society took place in 1966. The same monastic but efficient facilities will be prepared for this Seminar.

There will be mainly Round Table discussions on the suggested following topics:

The experimental criteria of an efficient assistance

Direct mechanical assist

Left ventricular by-pass

Veno-arterial by-pass

Synchronous pumping

Implanted artificial hearts

The assistance will be limited and admission will be on invitation only.

For information apply to: Institut de Recherches Chirurgicales, Centre Hospitalier Universitaire de Brabois, 54 NancyVandceuvre, France. 